\title{
Facile Syntheses of a Hexasaccharide and a Nonasaccharide Related to the Cell Wall D-Mannan of Yeast Candida albicans
}

\author{
Jun Ning and Fanzuo Kong* \\ Research Center for Eco-Environmental Sciences, Academia Sinica, P.O.Box 2871, \\ Beijing 100085, P. R. China
}

Received 2 September 1998; revised 2 December 1998; accepted 8 December 1998

\begin{abstract}
A highly efficient strategy for the preparation of D-manno-hexa- and nonasaccharides related to the cell wall $D$-mannan of yeast Candida albicans having $\alpha-(1 \rightarrow 6)$ - and $\alpha-(1 \rightarrow 2)$-linkages has been developed using 6-O-acetyl-2-O-benzoyl-3,4-di-O-benzyl- $\alpha$-D-mannopyranosyl trichloroacetimidate (7) as the key glycosyl donor in the "Inverse Schmidt" procedure. (c) 1999 Elsevier Science Ltd. All rights reserved.
\end{abstract}

Recently, Kanbe and Culter reported that the $\alpha$-linked oligo-D-mannosyl side-chains of a cell-wall Dmannan of the pathogenic yeast Candida albicans is in large part responsible for the binding of yeast cells to the marginal zone of mouse spleen. ${ }^{1}$ Stratford also noted the importance of $\alpha$-linked oligo-D-mannosyl sidechains of the cell wall D-mannan in the mechanism of several types of yeast flocculation. ${ }^{2}$ Furthermore, Nelson and co-workers reported that the alkali-released $\alpha$-linked $\mathrm{D}$-manno-oligosaccharides from $C$. albicans cellwall D-mannan were potent inhibitors of lymphoproliferation induced by the parent D-mannan. ${ }^{3,4}$ These facts are of interest from the viewpoints of both host-parasite interactions and the biological roles of cartohydrates.

The outer chain moiety of many yeast D-mannans has a long backbone consisting solely of $\alpha-(1 \rightarrow 6)$ linked D-mannopyranose units to which are attached various kinds of side-chains at $0-2$ in a comb-like structure. ${ }^{5.7}$ To elucidate the mechanisms of action of the biological effects of yeast mannans, it is of interest to synthesize different fragments of yeast D-mannans. Here we disclose a highly efficient strategy for the preparation of $\alpha-(1 \rightarrow 6)$-linked D-manno-oligosaccharides containing $\alpha-(1 \rightarrow 2)$-linked D-mannopyranose side-chains using 6-O-acetyl-2-O-benzoyl-3,4-di-O-benzyl- $\alpha$-D-mannopyranosyl trichloroacetimidate (7) as the key glycosyl donor in the "Inverse Schmidt" procedure. The syntheses of hexasaccharide 1 and nonasaccharide 2 related to the cell wall D-mannan of yeast Candida albican have been presented as typical examples.

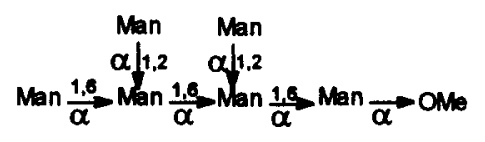

1

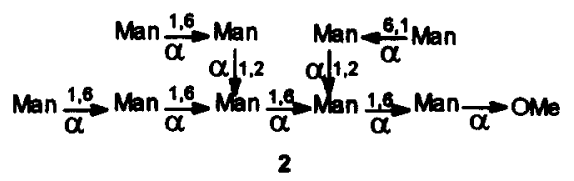


Methyl 2-O-benzoyl-3,4,6-tri-O-benzyl- $\alpha$-D-mannopyranoside (3) was prepared in $65 \%$ overall yield according to the literature using D-mannose as the starting material. Selective acetolysis of 3 using $\mathrm{HOAc} / \mathrm{Ac}_{2} \mathrm{O} / \mathrm{H}_{2} \mathrm{SO}_{4}{ }^{9}$ in a ratio of 6: $1: 0.05$ gave the corresponding diacetate 5 (Scheme 1). The concentration of $\mathrm{H}_{2} \mathrm{SO}_{4}$ should be controlled in the acetolysis, otherwise 1,4,6-tri-O-acetyl-2-O-benzoyl-3-O-benzyl- $\alpha$-Dmannopyranose (4) (Scheme 1, path a) was obtained. Compound 5 can be used directly as a glycosyl donor for preparation of some simple disaccharides by the Helferich method. Selective removal of the 1-O-acetyl group of the diacetate 5 was achieved using the conditions designated for selective removal of the 2-0trichloroacetyl group of 3,4,6-tri-O-acetyl-2-O-trichloroacetyl- $\beta$-D-glucopyranosyl chloride. ${ }^{10}$ Thus 6 was obtained in nearly quantitative yield by treatment of 5 in anhydrous ether saturated with dry ammonia. Subsequent reaction of 6 with $\mathrm{CCl}_{3} \mathrm{CN} / \mathrm{DBU}$ in dichloromethane afforded the key glycosyl donor $7 .^{11}$

Scheme 1

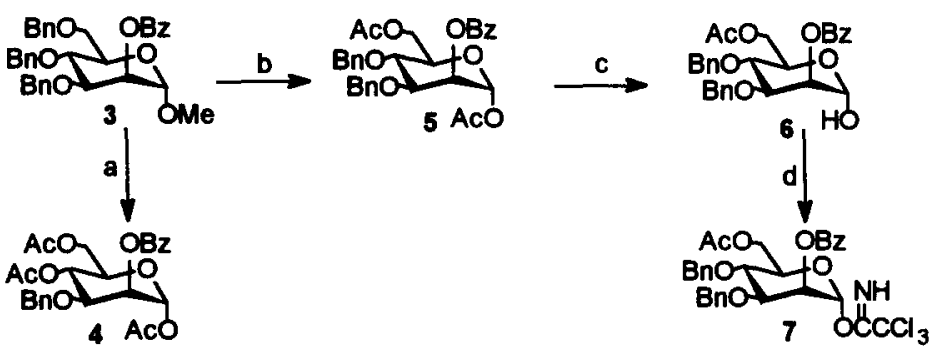

Reagents and conditions: (a) $\mathrm{HOAc} / \mathrm{Ac}_{2} \mathrm{O} / \mathrm{H}_{2} \mathrm{SO}_{4}=6 / 1 / 0.5$ (v/v), RT, $16 \mathrm{~h}, 95 \%$ (b) $\mathrm{HOAc} / \mathrm{Ac}_{2} \mathrm{O} / \mathrm{H}_{2} \mathrm{SO}_{4}=6 / 1 / 0.05$ (v/v), $\mathrm{RT}$, $16 \mathrm{~h}, 90 \%$ (c) anhydrous ether saturated with dry ammonia, $\mathrm{RT}, 24 \mathrm{~h}, 97 \%$.(d) $\mathrm{CCl}_{3} \mathrm{CN}$ (1.2 equiv.), DBU (0.2 equiv.), $0^{\circ} \mathrm{C}$, $2 \mathrm{~h}, 92 \%$.

As shown in Scheme 2, the disaccharide 9 was prepared by the Helferich reaction using 5 as the glycosyl donor and methyl 2,3,4-tri-O-benzyl- $\alpha$-D-mannopyranoside (8) as the acceptor. Selective removal of the acetyl group of 9 using a methanol solution containing $0.5 \% \mathrm{HCl}$ gave the glycosyl acceptor 10 quantitatively. The trisaccharide 11 was prepared using the "Inverse Schmidt" strategy. Thus the glycosyl acceptor 10 and the catalyst TMSOTf were mixed first in dry $\mathrm{CH}_{2} \mathrm{Cl}_{2}$, and after stirring for $15 \mathrm{~min}$, the glycosyl donor 7 was added dropwise within $30 \mathrm{~min}$ in order to get a high yield. The ${ }^{1} \mathrm{H}$ NMR spectrum of 11 showed one acetyl signal ( $\delta$ $1.98)$, one methyl signal $(\delta 3.25)$ and two $\mathrm{H}-2$ signal at downfield $(\delta 5.75,5.78)$, confirming the structure of 11. Removal of the acetyl group and the benzoyl groups of the trisaccharide 11 with a catalytic amount $\mathrm{NaOCH}_{3}$ in methanol gave quantitatively the glycosyl accepter 12 having free 6"'-OH, 2'-OH, and 2'- $-\mathrm{OH}$ groups respectively. "Inverse Schmidt" coupling of the triol 12 with 7 afforded the hexasaccharide 13 in $84 \%$ yield. The ${ }^{1} \mathrm{H} N M R$ spectrum ${ }^{11}$ of 13 showed three acetyl signals $(\delta 1.93,1.96$, and 1.98$)$, one methyl signal $(\delta$ 3.25 ) and three downfield H-2 signals ( $\delta 5.67,5.76$, and 5.86), characteristic of the structure of the hexasaccharide 13. Deprotection of 13 gave the title mannohexatose 1. We are gratified to find that selective tri-deacetylation of $\mathbf{1 3}$ using the same conditions as that used for selective deacetylation of 9 also afforded in nearly quantitative yield the glycosyl accepter 14 having three 6-OH groups. The fully protected nonasaccharide 15 was smoothly obtained using the "Inverse Schmidt" method again. The 'H NMR data of 15 contained structurally characteristic information, i.e. three acetyl signals $(\delta 1.91,1.93$, and 1.95$)$, one methyl 
signal ( $\delta 3.20)$ and six downfield H-2 signals $(\delta 5.68,5.75,5.76,5.77,5.80$ and 5.82). Deprotection of a nonasaccharide 15 gave the target mannononatose 2.

In summary, we have successfully developed a highly efficient strategy for the preparation of D-mannooligosaccharides i.e. reiteration of selective deacetylation of 9 or 11 followed by "Inverse Schmidt" coupling with 7 can afford $\alpha-(1 \rightarrow 6)$-linked tri- tetra-, and even higher oligosachharides, while Zemplén deacylation of the $\alpha-(1 \rightarrow 6)$-linked tri- tetra- oligosachharides followed by "Inverse Schmidt" coupling with 7 can afford comb-like or dendritical manno-oligosaccharide containing $\alpha-(1 \rightarrow 6)$ and $\alpha-(1 \rightarrow 2)$ linkages.

Scheme 2
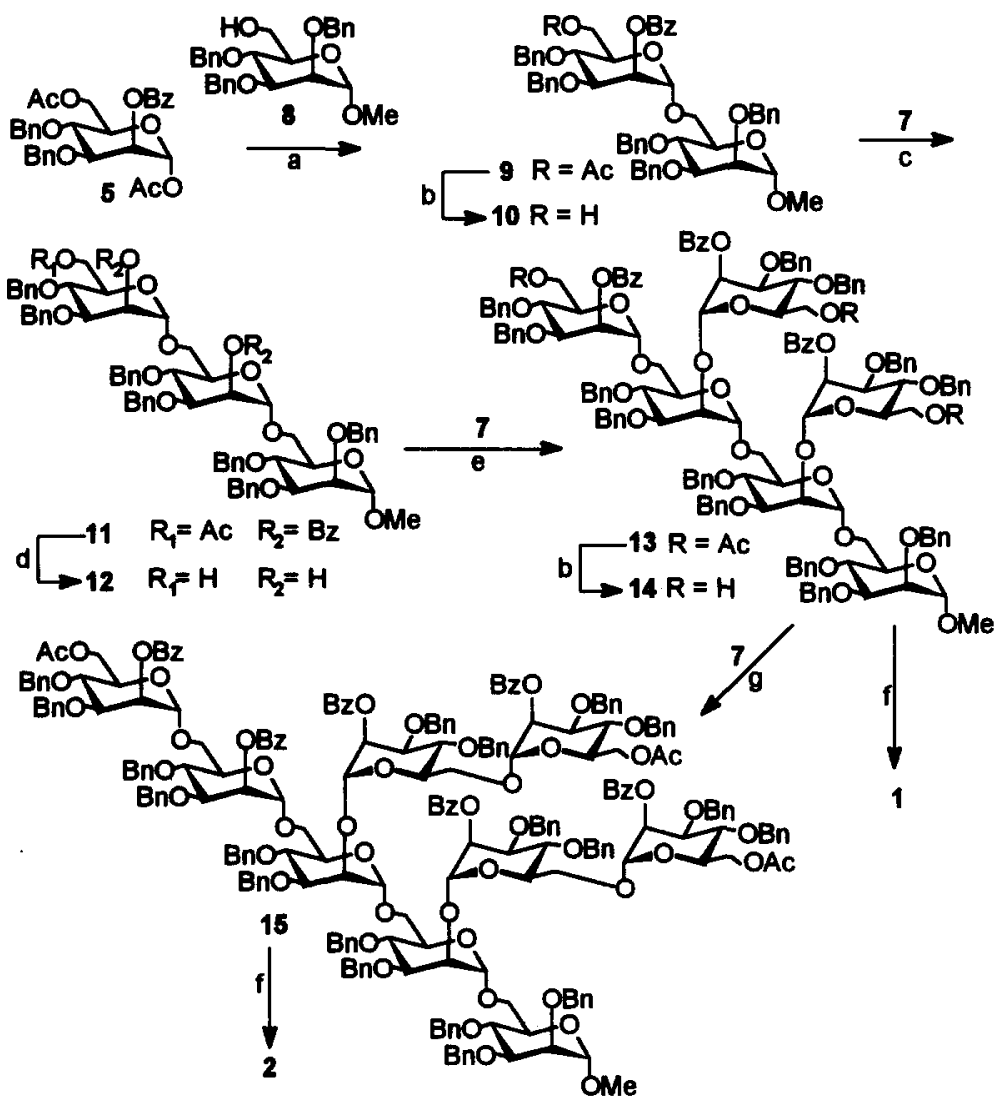

Reagents and conditions: (a) 8 (1.3 equiv.), $\mathrm{BF}_{3} \cdot \mathrm{OEt}_{2}$ (1.4 equiv.), $\mathrm{CH}_{2} \mathrm{Cl}_{2}, \mathrm{RT}, 85 \%$. (b) methanol/0.5\% $\mathrm{HCl}, \mathrm{RT}$., $18 \mathrm{~h}, 95 \%$. (c) 7 (1.3 equiv.), $\mathrm{CH}_{2} \mathrm{Cl}_{2}$, TMSOTf (0.1 equiv.), $0^{\circ} \mathrm{C}, 1 \mathrm{~h}, 94 \%$. (d) $\mathrm{CH}_{3} \mathrm{OH} /$ catalytic amount $\mathrm{NaOCH}_{3}, 96 \%$. (e) 7 (4.5 equiv.), $\mathrm{CH}_{2} \mathrm{Cl}_{2}$, TMSOTf ( 0.2 equiv.), $0^{\circ} \mathrm{C}, 1$ h, $84 \%$. (f) i. $\mathrm{CH}_{3} \mathrm{OH} /$ catalytic amount $\mathrm{NaOCH}_{3}$, ii. $\mathrm{H}_{2}, \mathrm{Pd} / \mathrm{C} 10 \%$, EtOAc, $\mathrm{RT}, 1 \mathrm{~h}, 95 \%$ for 1 and $93 \%$ for 2 .(g) 7 (6.0 equiv.), $\mathrm{CH}_{2} \mathrm{Cl}_{2}$, TMSOTf (0.2 equiv.), $0^{\circ} \mathrm{C}, 1 \mathrm{~h}, 66 \%$.

\section{ACKNOWLEDGEMENT}

Project 29672049 was supported by the National Natural Science Foundation of China. 


\section{REFERENCES AND NOTES}

1. Kanbe, T. and Culter, J.E. Infect. Immun., 1994, 62, 1662.

2. Stratford, M. Yeast, 1992, 8, 635.

3. Nelson, R.D.; Shibata, N.; Podzorski, R.P. and Herron, M.J. Clin. Microbiol. Rev., 1991, 4, 1.

4. Podzorski, R.P.; Gray, G.R. and Nelson, R.D. J. Immunol., 1990, 144, 707.

5. Nakajima, T. and Ballou, C.E. J. Biol. Chem., 1974, 249, 7679.

6. Suzuki, S.; Shibata, N. and Kobayashi, H. in J.P. Latge and D. Boucias (Eds), Fungal Cell Wall and Immune Response, NATO ASI Ser., Vol. H53 Springer-Verlag, Berlin, 1991, pp 111-121.

7. Kobayashi, H.; Kojimahara, T.; Takahashi, K.; Takikawa, M.; Takahashi, S.; Shibata, N.; Okawa, Y. and Suzuki, S. Carbohydr. Res., 1991, 214, 131.

8. Rachaman, E.S.; Eby, R. and Schuerch, C. Carbohydr. Res., 1978, 67, 147.

9. Wilson, J.D. and Durham, N.C. U.S. Patent. 4,921,950, 1990.

10. Lemieux, R.U. and Howard, J. Methods Carbohydr. Chem. II, 1963, 400.

11. All new compounds gave satisfactory elemental analysis results. Selected physical data for some key compounds are as follows: For 5: $\mathrm{mp}$ : $102-104^{\circ} \mathrm{C} ;[\alpha]_{\mathrm{D}}+3.2^{\circ}\left(\mathrm{c} 1.4, \mathrm{CHCl}_{3}\right) ;{ }^{1} \mathrm{H} \mathrm{NMR}\left(\mathrm{CDCl}_{3}, 400 \mathrm{MHz}\right): \delta$ 8.20-7.20 (m, 15H, 3PhH), $6.20\left(\mathrm{~d}, 1 \mathrm{H}, \mathrm{J}_{1.2}=2.1 \mathrm{~Hz}, \mathrm{H}-1\right), 5.62\left(\mathrm{dd}, 1 \mathrm{H}, \mathrm{J}_{1.2}=2.1 \mathrm{~Hz}, \mathrm{~J}_{2.3}=2.9 \mathrm{~Hz}, \mathrm{H}-2\right)$, $4.89,4.60(\mathrm{ABq}, 2 \mathrm{H}, \mathrm{J}=10.7 \mathrm{~Hz}, \mathrm{PhCH})_{2}, 4.83,4.61(\mathrm{ABq}, 2 \mathrm{H}, \mathrm{J}=11.9 \mathrm{~Hz}, \mathrm{PhCH}$ ), $4.34(\mathrm{~m}, 2 \mathrm{H}, \mathrm{H}-6,6$ '), $4.11(\mathrm{~m}, 1 \mathrm{H}, \mathrm{H}-5), 3.96(\mathrm{~m}, 2 \mathrm{H}, \mathrm{H}-3,4), 2.10,2.06\left(2 \mathrm{~s}, 6 \mathrm{H}, 2 \mathrm{COCH}_{3}\right)$. Anal. Calcd for $\mathrm{C}_{31} \mathrm{H}_{32} \mathrm{O}_{9}: \mathrm{C}, 67.88 ; \mathrm{H}$, 5.84. Found: $\mathrm{C}, 67.95, \mathrm{H}, 5.79$. For 7 : $\mathrm{mp}: 91-93^{\circ} \mathrm{C}$; $[\alpha]_{\mathrm{D}}+16.9^{\circ}\left(c 2.6, \mathrm{CHCl}_{3}\right) ;{ }^{1} \mathrm{H} \mathrm{NMR}\left(\mathrm{CDCl}_{3}, 400 \mathrm{MHz}\right)$ : $\delta 8.72\left(\mathrm{~s}, 1 \mathrm{H}, \mathrm{OC}(\mathrm{N} H) \mathrm{CCl}_{3}\right), 8.10-7.10(\mathrm{~m}, 15 \mathrm{H}, 3 \mathrm{Ph} H), 6.36\left(\mathrm{~d}, 1 \mathrm{H}, \mathrm{J}_{1,2}=2.1 \mathrm{~Hz}, \mathrm{H}-1\right), 5.73\left(\mathrm{t}, 1 \mathrm{H}, \mathrm{J}_{1,2}=\mathrm{J}_{2,3}=\right.$ $2.1 \mathrm{~Hz}, \mathrm{H}-2), 4.90,4.64$ (ABq, $2 \mathrm{H}, \mathrm{J}=10.8 \mathrm{~Hz}, \mathrm{PhCH}_{2}$ ), 4.82, $4.61\left(\mathrm{ABq}, 2 \mathrm{H}, \mathrm{J}=11.3 \mathrm{~Hz}, \mathrm{PhCH}_{2}\right.$ ), 4.35 (dd, $\left.1 \mathrm{H}, \mathrm{J}_{6,6^{\circ}}=11.9 \mathrm{~Hz}, \mathrm{~J}_{5,6} 1.7 \mathrm{~Hz}, \mathrm{H}-6\right), 4.30\left(\mathrm{dd}, 1 \mathrm{H}, \mathrm{J}_{6,6^{\circ}}=11.9 \mathrm{~Hz}, \mathrm{~J}_{5,6^{\circ}}=3.4 \mathrm{~Hz}, \mathrm{H}-6^{\prime}\right), 4.17\left(\mathrm{dd}, 1 \mathrm{H}, \mathrm{J}_{2,3}=2.1 \mathrm{~Hz}\right.$, $\left.\mathrm{J}_{3,4}=8.7 \mathrm{~Hz}, \mathrm{H}-3\right), 4.1\left(\mathrm{t}, 1 \mathrm{H}, \mathrm{J}_{3,4}=\mathrm{J}_{4,5}=8.7 \mathrm{~Hz}, \mathrm{H}-4\right), 4.02\left(\mathrm{~m}, 1 \mathrm{H}, \mathrm{J}_{5,6}=1.7 \mathrm{~Hz}, \mathrm{~J}_{5,6}=3.4 \mathrm{~Hz}, \mathrm{~J}_{4,5}=8.7 \mathrm{~Hz}, \mathrm{H}-\right.$ 5), $2.03\left(\mathrm{~s}, 3 \mathrm{H}, \mathrm{COCH}_{3}\right.$ ). Anal. Calcd for $\mathrm{C}_{31} \mathrm{H}_{30} \mathrm{O}_{8} \mathrm{Cl} 3 \mathrm{~N}: \mathrm{C}, 57.19 ; \mathrm{H}, 4.61$. Found: $\mathrm{C}, 57.42 ; \mathrm{H}, 4.60$. For 13: $[\alpha]_{\mathrm{D}}+19.5^{\circ}\left(c 2.2, \mathrm{CHCl}_{3}\right) ;{ }^{1} \mathrm{H} \mathrm{NMR}\left(\mathrm{CDCl}_{3}, 400 \mathrm{MHz}\right): \delta 8.06-7.09(\mathrm{~m}, 80 \mathrm{H}, 16 \mathrm{Ph} H), 5.86,5.76,5.67(3 \mathrm{t}, 3 \mathrm{H}$, $3 \mathrm{H}-2$, geminal to $\mathrm{BzO}), 3.25\left(\mathrm{~s}, 3 \mathrm{H}, \mathrm{OCH}_{3}\right), 1.98,1.97,1.93\left(3 \mathrm{~s}, 9 \mathrm{H}, 3 \mathrm{COCH}_{3}\right) ;{ }^{13} \mathrm{C} \mathrm{NMR}\left(\mathrm{CDCl}_{3}, 400 \mathrm{MHz}\right): \delta$ $170.7,170.6,170.5\left(3 \mathrm{CH}_{3} \mathrm{CO}\right), 165.2(2 \mathrm{COPh}), 165.0(\mathrm{COPh}), 138.5-133.1$ (quaternary $\left.\mathrm{C}\right), 130.1-127.2$ $(\mathrm{PhCH}), 99.59,99.57 .99 .10,98.91 .98 .72,98.70(6 \mathrm{C}-1), 54.7\left(\mathrm{OCH}_{3}\right), 21.06-20.8\left(3 \mathrm{COCH}_{3}\right)$. Anal. Calcd for $\mathrm{C}_{155} \mathrm{H}_{160} \mathrm{O}_{37}$ : C, 71.21; $\mathrm{H}, 6.12$. Found: $\mathrm{C}, 71.37 ; \mathrm{H}, 6.09$. For 1: ESMS Calcd for $\mathrm{C}_{37} \mathrm{H}_{64} \mathrm{O}_{31:}$ 1004.88[M]. Found: $1003[\mathrm{M}-\mathrm{H}]^{+}$. For 15: $[\alpha]_{\mathrm{D}}+20.3^{\circ}\left(\mathrm{c} 1.1, \mathrm{CHCl}_{3}\right) ;{ }^{1} \mathrm{H} \mathrm{NMR}\left(\mathrm{CDCl}_{3}, 400 \mathrm{MHz}\right): \delta 5.825 .805 .775 .76$ $5.755 .68(6 \mathrm{t}, 6 \mathrm{H}, 6 \mathrm{H}-2$, geminal to $\mathrm{BzO}),, 3.20\left(\mathrm{~s}, 3 \mathrm{H}, \mathrm{OCH}_{3}\right), 1.95,1.93,1.91\left(3 \mathrm{~s}, 9 \mathrm{H}, 3 \mathrm{COCH}_{3}\right)$. Anal. Calcd for $\mathrm{C}_{236} \mathrm{H}_{238} \mathrm{O}_{55}$ : C, 71.70; $\mathrm{H}, 6.02$. Found: $\mathrm{C}, 71.76 ; \mathrm{H}, 6.00$. For 2: ESMS Calcd for $\mathrm{C}_{55} \mathrm{H}_{94} \mathrm{O}_{46}:$ : $491.30[\mathrm{M}]$. Found: $1490[\mathrm{M}-\mathrm{H}]^{+}$. 